\title{
Health teaching-service integration: possible dialogues from collective co-management
}

Integração ensino-serviço em saúde: diálogos possíveis a partir da cogestão de coletivos Integración ensino-servicio en salud: diálogos posibles a partir de la cogesión de colectivos

Carine Vendruscolo ${ }^{2}$ (1]

Fabiane Ferraz ${ }^{3}$ (1)

Letícia de Lima Trindade ${ }^{2,5}$ (D)

Daiana Kloh Khalaf ${ }^{4}$ (D)

Maria Elisabeth Kleba ${ }^{5}$ (1)

Marta Lenise do Prado ${ }^{1}$ (10)

1. Universidade Federal de Santa Catarina.

Florianópolis, SC, Brasil.

2. Universidade do Estado de Santa Catarina.

Chapecó, SC, Brasil.

3. Universidade do Extremo Sul Catarinense.

Criciúma, SC, Brasil.

4. Universidade Federal do Paraná.

Curitiba, PR, Brasil.

5. Universidade Comunitária da Região de

Chapecó. Chapecó, SC, Brasil.
Corresponding author:

Carine Vendruscolo.

E-mail: carine.vendruscolo@udesc.br

Submitted on $08 / 13 / 2018$.

Accepted on 10/01/2018.

DOI: 10.1590/2177-9465-EAN-2018-0237

\section{Abstract}

Objective: To analyze the Pró-Saúde management from an intersectoral dialogical space of teaching-service integration. Method: A case study whose information was produced by observing meetings of intersectoral management instances and interviews with Health Training Prism members, between 2012 and 2013. We used the operational proposal for the analysis of qualitative data, in the light of the Paideia Training and Support Methodology for collective co-management. Results: The instances presented themselves as a democratic possibility of sharing the power of representatives of the university (field of theory) and service (field of practice), consonant with the Paideia Support. However, it is necessary for the people involved to appropriate strategies that encourage the reorientation of teaching and to qualify listening in the collective space. Final considerations: Training reorientation processes co-management, fostering the dialogue between teaching and service, ramp up praxis in health management and enable changes in training and health care.

Keywords: Unified Health System; Management in Health; Primary Health Care; Nursing Education; Higher Education.

\section{Resumo}

Objetivo: Analisar a gestão do Pró-Saúde a partir de um espaço dialógico intersetorial de integração ensino-serviço. Método: Estudo de caso, cujas informações foram produzidas mediante observação de reuniões de instâncias gestoras intersetoriais e entrevistas com membros do Prisma da Formação em Saúde, entre 2012-2013. Utilizou-se a proposta operativa para análise de dados qualitativos, à luz da Metodologia de Formação e Apoio Paidéia para a cogestão de coletivos. Resultados: As instâncias se apresentaram como possibilidade democrática de compartilhamento de poder dos representantes da universidade (campo da teoria) e do serviço (campo da prática), consonante com o Apoio Paidéia. Contudo, é necessário que as pessoas envolvidas se apropriem das estratégias que fomentem a reorientação do ensino e qualifiquem a escuta no espaço coletivo. Conclusão: A cogestão de processos de reorientação da formação, ao fomentar o diálogo entre ensino e serviço, potencializa a práxis na gestão em Saúde e viabiliza mudanças na formação e na atenção à saúde.

Palavras-chave: Sistema Único de Saúde; Gestão em Saúde; Atenção Primária à Saúde; Educação em Enfermagem; Educação Superior

\section{REsumen}

Objetivo: Analizar la gestión del Pró-Saúde a partir de un espacio dialógico intersectorial de integración enseñanza-servicio. Método: Estudio de casos, cuyas informaciones fueron producidas mediante observación de reuniones de instancias gestoras intersectoriales y entrevistas con miembros del Prisma de la Formación en Salud, entre 2012-2013. Se utilizó la propuesta operativa para análisis de datos cualitativos, a la luz de la Metodología de Formación y Apoyo Paidéia para la cogestión de colectivos. Resultados: Las instancias se presentaron como posibilidad democrática de compartir el poder de los representantes de la universidad (campo de la teoría) y del servicio (campo de la práctica), consonante con el Apoyo Paidéia. Sin embargo es necesario que las personas involucradas se apropien de las estrategias que fomenten la reorientación de la enseñanza y califiquen la escucha en el espacio colectivo. Consideraciones finales: La cogestión de procesos de reorientación de la formación, al fomentar el diálogo entre enseñanza y servicio, potencializa la praxis en la gestión en Salud y viabiliza cambios en la formación y en la atención a la salud.

Palabras clave: Sistema Único de Salud; Gestión en Salud; Atención Primaria de Salud; Educación en Enfermería; Educación Superior. 


\section{INTRODUCTION}

The different approaches that represent social organizations in Health have been widely discussed, observing the context of complex practices in which professionals operate the technologies in Health. The Paideia Training and Support Methodology operates from praxis as a democratic possibility of sharing power in collective spaces for the co-management of work and health networks. ${ }^{1,2}$ It is a way of building conditions for the dialogical reflection from different conceptions of the world, proposing an increase in the comprehension and intervention capacity of subjects in a given context, and reflecting on others and on themselves, with a view to democracy and social well-being. ${ }^{1-4}$

In the context of Primary Health Care (PHC), the Paideia Support is an excellent strategy for the co-determination of the intercessory space between the both of worlds of doing and knowing in Health, at this care level. ${ }^{2}$ This methodology increases the subject's ability to understand and act from a network of interdependencies, placing the conflict under analysis and agreeing on the construction of interdisciplinary proposals, in order to qualify professional training and development in Health. ${ }^{1,5}$ By making possible the articulation between theory and practice, the teaching-service integration is at the service of reflection for the transformation of reality, mobilizing a permanent effort of critical perception about the world, with a view to the adequate solution and the commitment to the resolution of problems (problematizing education). ${ }^{6,7}$

In Brazil, the participation of users in decision-making instances in Health is a right guaranteed by law. Through a "social control" action, it is exercised, in particular, on management councils, which are influenced by sociocultural and historical factors, such as the lack of a participatory tradition and weaknesses in civic and political culture. ${ }^{8,9}$ We hope that these spaces, with representations of the different social actors involved, can operate as a locus of sharing decision-making power through dialogue and general responsibility. In the scope of the training process reorientation in Health, researchers ${ }^{8}$ defend the "Health Training Prism" as a representative figure in the construction and management of education within the Brazilian Unified Health System (SUS - Sistema Único de Saúde). The ideology of such a figure presupposes that each of the actors involved in the training process establishes specific movements, through an innovative interaction between interlocutors, with different points of view and understandings, reflecting on different possibilities, from the established connections (as if it were a prism, whose white light that penetrates in reflects of multicolored form). This involves, necessarily, the dialogue between representations of social control, health care, management and teaching, considering the unfolding of these segments (students, professors, workers, professionals, managers, supporters, among others). In the Health Training Prism, the levels of involvement of the different subjects of the involved instances are determinant for the formation of care networks, in which the actors are involved and constitute relations of integration between teaching and service. ${ }^{5,8}$
In this context, the Reorientation National Program for Health Professional Training (Pró-Saúde - Programa Nacional de Reorientação da Formação Profissional em Saúde), created in 2005, through the Labor Management and Health Education Office and Ministry of Health (MoH), in partnership with the Higher Education Office, of the Ministry of Education, aimed at promoting the articulation between teaching institutions and health services, in order to carry out the planning and development of health practices consistent with the loco-regional reality. ${ }^{5,10}$ In this reality, the teaching and care segments are inserted, which contributes to the training of professionals, aligned with the guidelines of the SUS. ${ }^{5}$ For this, the Pró-Saúde involved professors and students of Higher Education Institutions (HEI) and professionals of the services considering the teaching-service interaction as a fundamental element in the development of strategies that overcome the organizational challenges of professional training in health. . $^{5,10,11}$

Pró-Saúde has instituted, nationally, an Executive Committee and an Executing Commission, as well as an Advisory Board to monitor the implementation of projects, including government representatives of professional instances, heads of teaching institutions and student entities. At the state level, in addition to these three instances, the Monitoring Committee was created and, at the municipal level, the Local Management and Monitoring Commission, to monitor and evaluate projects in the territory. This includes a coordinator of the project and the following representations: the municipal health manager, the Municipal Health Council (MHC - Conselho Municipal de Saúde), the SUS professionals, the educators and the students of the $\mathrm{HEI}$ executing courses that participate in the project. ${ }^{5}$

From the overview presented, the question is: how does the management of the Pró-Saúde in instances that are spaces of encounter between the actors that represent the teaching and the service in Health?

The present study aims to analyze the management of Pró-Saúde from a dialogical and intersectoral space of teaching-service integration. It was sought the understanding of the representatives of different segments that compose these instances on the integration teaching service, its potentialities and fragilities, based on this democratic movement.

With the debate, it is intended to contribute to the expansion of the theoretical construct and the applicability of teachingservice integration as a management praxis, ${ }^{2}$ based on the organization of SUS's network of services and PHC as coordinator.

\section{METHOD}

It is a case study, ${ }^{12}$ developed with representatives of the education (teaching) and work (service) segments, whose actors and their expressions conform the Health Training Prism, in intersectoral instances of management of the training reorientation processes in Health, existing in the Universidade Comunitária da Região de Chapecó (Unochapecó), located in the West of Santa Catarina (SC) State, Southern Brazil. Unochpecó's 
Pró-Saúde is developed in partnership with the Municipal Health Office (MHO - Secretaria Municipal de Saúde) and the Regional Health Management (GERSA - Gerência Regional de Saúde) of Chapecó/SC. These projects had as local management managers forums the Local Management Committee (LMC) and the General Coordination Committee (GCC). ${ }^{10}$

Coherent with the guidelines of the Pró-Saúde Program, LMC was, at the time, composed of 16 members, representatives of the management, care, teaching and social control segments. The LMC was composed of representatives of the teaching and the service, with 23 full members. These structures met in monthly assemblies, mostly at the $\mathrm{HEI}$ headquarters, constituting spaces for planning and monitoring the implementation of activities proposed by the Project. They were meetings to report difficulties, perceive possibilities, reveal initiatives, make decisions and define referrals about programs related to interministerial devices. ${ }^{5}$

For the production and recording of information, focused interviews ${ }^{5,10,12}$ and direct observation were conducted between October 2012 and February 2013. The interviews were conducted with six participants (three teaching representatives and three service representatives), chosen, intentionally, by the researchers. The questions focused on how the members of the management intersectorial instances of training reorientation actions perceived the teaching-service integration, from the existence of this space of discussion; the potential and weaknesses of this integration, in the perspective of intersectoral dialogue. The data saturation criterion ${ }^{13}$ was used when the characterization of a given pattern was observed in the speeches that expressed the sufficiency of information for the study, and then the information production was suspended. 5,10

In the direct observation, the study had 25 participants, identified in the period of information gathering as participants in the instances, and who were present at the moments of observation of the meetings. Inclusion criteria were: to have participated in one of the intersectoral management instances and to represent one of the teaching or service segments, from 2006 to 2012. Persons who were retired or absent (medical leave, vacation, etc.) were excluded from the group during the information collection period. 5,10

There were six moments of observation meetings of the instances, totaling 18 hours, recorded in Field Diary. This preelaborated observation tool contained: Descriptive Observation Notes (DON), which recorded relevant aspects of organization, planning and dynamics of meetings and Reflection Observation Notes (RON), which contained the processes of dialogue, participation, conflicts and other observations of the interviewer. Due to the dynamics and number of participants present (average of 12), there was no need for more than one observer. ${ }^{5,10}$

The information was collected based on the analysis of qualitative data, ${ }^{13}$ defining categories: a) action-reflection-action space: daily vigil and mobilization of subjects; b) place of exposition of points of view and otherness: recognizing roles. Subsequently, the information was discussed from the perspective of
Paideia Training and Support Methodology, also known as Wheel Method, proposed by Campos et al and collaborators. ${ }^{1-4}$

The training and Support Paideia is a theoretical-methodological conception, whose purpose seeks to favor the democratization of the management in organizations, through the formation of organized collectives, encouraging the participation of subjects in the management of their work processes. In this logic, the reform of health organizations is sought based on co-management, that is, on the establishment of dialogic relations, sharing knowledge and power. ${ }^{1-3,14}$ This proposal criticizes the referral and counterreferral model, since it considers this type of relationship vertical, hierarchical, bureaucratic and not dynamic, in which the difference of authority between the one who forwards a case and the one who receives it is accentuated. This logic, experienced in different health contexts, ${ }^{14,15}$ implies the indissolubility of care and management and ponders about the need for management support as a face of the support function, also present in the Support Paideia. Support, as a democratization device, seeks the participation of managers, workers and users in the formulation, performance, evaluation of work in Health, promoting democratic management of the service.

It should be noted that the ethical aspects, such as the acquisition of permission from the instances involved, as well as the favorable opinion of the Committee of Ethics in Research with Human Beings of the Universidade Federal de Santa Catarina (UFSC), under number 242.966/2012, meeting the criteria of the Resolution 466/2012.5,10 After formal presentation of the objectives of the study, the guests who accepted to participate in the study signed the Informed Consent Term. In order to guarantee anonymity, the participants were identified by numbers corresponding to the interviews, followed by the letter of the segment represented (Teaching - T; Service - S), such as interview 01 - $\mathrm{T}$; interview 02 - $\mathrm{S}$, and so on.

\section{RESULTS}

At the time of the information production, the participants in the majority of the instances were women, who came from different areas of Health education and had an average time of involvement in the two and a half years. Considering the total number of participants from both structures, the $\mathrm{LMC}$ and $\mathrm{CCL}$ participants were representatives of the teaching segment (14, between students and professors); five of the care segment (health professionals); four managers (PHC sector coordinators, designated by the municipal manager to participate in the meetings) and two representatives of social control (health professionals who participated in the MHC). ${ }^{5,10}$

The process of dialogue was organized as follows: the participants were arranged around the table, the coordinator laid out the agenda and mediated the dialogical movement; each one was registered to issue the considerations on the point. The meetings lasted three hours on average. It was also possible to record moments of study of Interministerial Ordinance; exposure or results of projects; marked participation of some professors 
and professionals; little participation of students, representatives of social control and managers; and some more conflicting discussions between the teaching and service segments.

The dialogues that are established during the meetings of the managers of the Pró-Saúde develop orderly, foment new ideas, moments of study and reflections of the actors that belong to the different segments represented on the Pró and also on Pet-Saúde1 as possibilities of reorientation of health training. There are also times of negotiation, sometimes conflicting (RON - researcher).

From the six meetings observed, it was possible to verify the presence of two different management representatives in the meetings, now acting as incumbents, alternates, new members, and did not always understand their role and which segment belonged, as is clear in the notes following observation:

Representative of the manager: my name is [name], I work at [health institution], it is the first time I am serving, at the request of the [Health Office] I will stay longer to listen because I do not know exactly the Pró-Saúde (DON - manager segment).

In presenting themselves, management participants who appear for the first time in the instance, manifestly do not understand, exactly, what their role in that space and what it is. Possibly, when receiving the call, the titular manager sends a substitute and, failing that, a new representative, without explaining what it is (RON - researcher).

The observation of the meetings allowed us to understand the organization and movement of management spaces, how the dialogues, the participation, the conflicts, among other impressions, were organized from the perspective of the researchers; and the focused interviews allowed doing so, from the point of view of the participants. In the following, we present the categories that composed the results:

\section{Action-reflection-action space: daily vigil and mobilization of subjects}

Based on the dimension of the reconstruction of the practices of subjects, as for the impression of the intersectoral spaces of management of the devices that induce the reorientation of the training, the statements express the mobility produced by the service, from the possibilities of change in the daily work, with the presence and influence of teaching, called "impact". It is, from its point of view, an articulating space:

[...] I think it is very important that this instance, with members of the University and the Health Office, can then plan and study about the progress of the Pró-Saúde and its impact on the service, have this notion of what changes [...] the role is this: to make this joint (Interview 01 - S).
The representatives of the teaching segment highlight the pedagogical and integration aspects between teaching and service, with a view to consolidating devices that induce the reorientation of training, such as Pró-Saúde. Integration takes place in the problematization, in the dialogue and, above all, in the transformative movement: from the collegial instance in a teaching-learning place, from theory to practice and from health spaces in "living written material". This transformation also translates into the subjects that compose that instance.

This is a space that makes us think more about the importance of this [teaching-service integration], by being in that place, becomes more connected, more concerned with the actions, and in doing, in taking that care [...] it is problematic how [Pró and Pet-Saúde] projects can be implemented, from how each space has seen, how the teaching sees, how the service sees, I think we have made progress in this process (Interview $02-T$ ).

[...] a place of study, a partner site in the process of reorientation of training [...] ends up being a pedagogical space, and has nothing more interesting to transform actions of services or training, than transforming instances into living pedagogical spaces, where you can learn continuously [...] (Interview $03-T$ ).

The possibility of reflecting is pointed out, among other things, both on relationships in the field of teaching, and on their involvement in service, on constant thinking, which monitors "watches" - the work process and modifies daily life:

[...] [the intersectoral instance] makes this care easier [...] in relation to the teaching-service relationship. It allows this closer look, as if, in some way, it was a vigilant of the own work [...] I think they are spaces that make people think (Interview 02 - T).

Intersectoral instances are understood as pedagogical settings, which, through the dialogue of the participants, provoke movements in training (teaching) and care (service), revealing the confluence of forces arising from the subjects, with others, of the social reality in which they are inserted.

\section{Place of exposition of points of view and otherness: recognizing roles}

From the point of view of the power struggle in the world of teaching and service, study participants recognize theory and practice as tools of these organizations. They, however, consider a complementarity between them. In this direction, the management instances offer a space for reflection on what is done.

[...] then comes that story, which practice is very different than theory [...] needs that all people are really thinking that way (Interview 04 - S). 
[...] space that makes us think more about the importance of the university, because being there gets you more connected, more aware on your actions, on doing [...] reflecting [...] (Interview 05 - T).

During the meetings of the instances, similar statements are expressed by the representatives of the different segments, based on evaluations requested by the process coordination:

Participants who represent the teaching segment refer that the instances are deliberative spaces, where each one to have clarity about the role it represents (DON teaching segment).

Participants representing the management segment consider that the forums are opportunities to approach the service with health teaching (DON - management segment).

Participants who represent the care segment believe in the possibility of putting themselves in the place of the other and exercising the representation with responsibility, through participation in the management forums (DON care segment).

The movement of thinking about what is done also fosters the recognition of the roles of each sector and each participant. In addition to recognizing themselves in the process, the management instances provoke the exercise of putting themselves in the place of the other, in an expression of otherness.

From the meetings, I think it is problematized [...] how projects can be implemented, from how each space has seen, how the teaching sees, how the service sees, so I think we have advanced in this process (Interview 05 - T).

However, for some participants in management forums, the process of recognizing these possibilities requires time to appropriate this management structure and, gradually, to learn to manage conflicts between the both worlds of doing and knowing in Health. Moreover, it lacks a more correct orientation regarding the form of definition as to the representation exercised in the manager space. In the following speech, the representative of the service segment manifests itself over the period of time needed until he understands his role in the instance:

I think it is lack of knowledge indeed! What am I doing here? So much so that when I voiced this, other people also said! [...] the University, because it is the representative of knowledge, sometimes also puts it this way: "Look, I instrumentalize you, because I know!" (Interview 06 - S).
The note confirms this perspective and also points to the importance of the manager's involvement in the process, from a speech of his that was thus translated:

The manager's representative, present at the meeting, assures that each one has a different time to understand the proposal of the forums, as well as the Pró-Saúde and that, when trying to exercise his representation by passing information to the manager, he cannot always convince him the importance of this integration (DON - representative of the management segment).

The exercise of shared management is implied in the speeches of the participants of the instances, as there are different levels of knowledge and power. Negotiation movements, conflict mediation and articulated composition of projects in which the difference of roles and power between the different social actors is reflected in integration and otherness. In this movement, it is considered an important step to understand as a representative of a segment, not only as a spokesperson for another person or group, but being listened, as subject, in a given historical time.

\section{DISCUSSION}

Participation, as the engine of transformation and democratization of subjects, occurs through praxis. It can be understood as a concrete activity in which the subject recognizes himself in the world, continually modifying objective reality in a reflective way, articulating theory and practice..$^{6,17}$ In proposing to go beyond the sphere of the apprehension of reality to a critical sphere of consciousness, Freire explains that consciousness cannot exist outside praxis, that is, without action-reflection, for this dialectical unity is permanently the way of being or the possibility of transforming the world that characterizes the people, taking into account its complex and interactive nature. ${ }^{6,18}$ With this same perspective, coproduction is one of the key concepts of the Paideia Method. It consists in the possibility of seeing the world from forces derived from internal and external values, recognizing the contradictory and unfinished character of the subject, with a view to autonomy. ${ }^{1,2}$ Understanding reality demands a position before it and facing the world; for or against a particular situation. In democratic processes, this means opting for decentralization, as opposed to the centralization of power as a form of active participation in the decision-making process.

The analysis of the inter-sectorial instances of management that configure the case demonstrates structures that operate as an intercessory space for the overlap between the world of teaching and service, which favors the teaching process aimed at social transformation. ${ }^{6}$ It should be emphasized that effective training - with a view to transformation - cannot take place without taking into account the real needs of social subjects in the sphere of their historical and social context. ${ }^{6,17}$ 
This dimension is well evident in the critical position assumed by the subjects, representatives of the different segments, in expressing their impression of Pró-Saúde and of the instances. They are, moreover, these critical perceptions that make them protagonists of the process, characterizing the Health Training Prism. ${ }^{5,8,10}$ Moreover, it is necessary to consider the relations between theory and practice in a first plane, in which the first depends on the second, these results from the first and both give meaning to the social reality, springing from them the progress of knowledge..$^{19} \mathrm{As}$ a locus of management, these intercessory spaces have encouraged the exercise of taking into account the complexity and the multidimensionality of subjects and relations between them, as well as the role of the different segments represented there.

In relation to the representation of the different segments, there is a conception that, in the managing councils, in general, appointed groups act in the interest of pre-defined audiences. In this case studied, it is perceived the need of a time for effective appropriation of the process by the representative subjects; that they feel "heard" in that space.

When considering a philosophy of practice, the subject of intervention is certainly a fundamental element. The theory without practice presents itself as a naive conception of the world, whose network of concepts, without the proper relations and modes of applicability to reality, would have no meaning. ${ }^{6,17}$ In the case analyzed, there is a healthy tendency to reduce the differences between university and health services, between academics and workers. Cohesion works as a way of articulating knowledge, with a view to achieving both structures and producing quality health.

Another dimension, perceptible from the possibility of approaching education and service in intersectoral instances, in this perspective of support and co-management, is the possibility of transforming social relations, which implies modifications in subjects' ways of thinking and acting, a process conversion and conformation of new values. ${ }^{1,2}$ Assuming themselves as citizens, changing the posture of spectators by that of subjects/protagonists, the representatives of the different segments that perceive themselves in this condition assume responsibilities, commit themselves, participate and develop a sense of belonging, surpassing the sphere of simple "spokesman" of the represented.

However, the lack of professionals who represent all the segments that compose the forums implies the discontinuity of the representativities. In assuming the collegiate structure, one bets on the change, since the traditional organizational hierarchies disfavor the sharing of the decision-making power. In the case of Pró-Saúde management instances, the effectiveness of the organizational structure still depends on the negotiation capacity and the effective transformation of the individuals involved. Thus, it is possible to consider that although there is significant progress, the responsibilities of each segment remain dubious, after all, teaching and service are two worlds supposedly articulated, but operating with still different logics.
The Paideia Methodology does not conceive of social organization without the contest of power but, on the other hand, considers this dispute essential to democracy. It advocates, however, ensuring the resolution of conflicts through the use of persuasive and negotiating tools. Thus, it invests in the existence of shared projects from the management that encourages the exit of oneself, without, however, abandoning oneself. The same demands a process in which the subjects can express their interests and desires, rethinking them from the interests and desires of the others, according to the context and institutional impositions..$^{2-4,14}$ It is assumed, therefore, that the management functions are exercised between subjects with different levels of knowledge and power, dealing with affections through negotiation, otherness, conflict mediation, participating actively and effectively.

The analysis of the discourses refers to the potentiality of a space that gives life to the anxieties coming from the existential networks, formed by professors, students, workers, managers and users, through their representatives, generating possibility of changes in work processes, with a view to resolvability of PHC. The concept of network here must be understood in its broadest sense, where each node is constituted according to its connections and articulations with other nodes, from a relational perspective and not individual or unidirectional. ${ }^{20}$

The representatives mention a space that gives voice to what is performed, as a living work. In this context, significant learning, the process of learning to learn, in which everyday problems are taken as a source of learning. In the logic of active teaching-learning methodologies, there is room for innovative and necessary pedagogical frameworks for the promotion of changes, aiming at integrative and democratic practices. ${ }^{6,21,22}$

Also, new perspectives on health work reveal that its reorganization must also include the implementation of teaching and training processes of the workforce based on the provision of care, which is capable of providing the users with the necessary care and/or resolution. ${ }^{23-24}$ Thus, education must be taken as a motivator to strengthen the health system..$^{25,26}$

In this direction, the instances also act as boosters of Permanent Health Education movements, above all by strengthening the actors of the Health Training Prism, for the resolutiveness. ${ }^{5,11,16}$ From this point of view, management based on support is a democratic device for discussion and decision that broadens the spaces for listening, exchange and collective decision-making in work processes. ${ }^{23}$

Considering the different points of view that were highlighted in this analysis and which, therefore, generate conflicts, it is necessary to emphasize that the controversies are a complex phenomenon of collective life. Thus, situations in which actors disagree, as a rule, begin when they discover that they cannot ignore each other and end when they can work out a concrete commitment to live together. In this direction, the controversies present, in common, the fact of involving all types of actors, being dialogued and without conflicts. ${ }^{20,27}$ 
Therefore, it seems fruitful that there is a space destined to such arguments, with the proposition of a pedagogical dimension in which the actors coming from teaching and work in Health can act, from the dialogue about their practices, in the new model of care. This dimension must combine the attributes of each subject with the context from which they come, in an integrated logic, which approaches theory and practice, as well as the incorporation of ethical values.

\section{FINAL CONSIDERATIONS}

From the research on teaching-service integration and its expression in intersectorial management instances, it was possible to perceive the power of the approximation of these spaces (of knowledge and of doing) in the production of health. This is mainly due to the possibility of materializing theory in practice and vice versa, as a living process.

The shared management of training reorientation processes co-management for SUS makes it possible to think about the practice and the recognition of the subject and its role in this context. Thus, the dialogues of co-management are analyzed as a locus of learning and transformation that can impact on the qualitative production of health.

Paideia Support was visualized as a tangential method (even if not assumed) in the case observed, since the work comanagement, based on praxis, was presented as a democratic strategy of power sharing - university and service. Dialogic reflection, based on different conceptions of the world, seems to foster the capacity of social actors to understand and intervene in a given reality, in the search for a common objective, reaffirming that collective spaces of co-management and agile processes of communication enable changes in training and health care.

Thus, the co-management of processes that induce the reorientation of training fosters interlocution between teaching and service, promotes praxis, provoking different subjects about their role and power in the process. Intersectoral spaces function as a network of fruitful relationships, whose participation is productive and emancipatory, giving the subjects subjectivity capable of transformation, proper to the Paideia Method. It is understood that the strengthening of these aspects can contribute to the greater role of SUS' professionals.

The case study observes a specific reality and, by the very composition of the instances, did not allow an equitable representation of all the segments, common limit in the researches that approach management and training in Health. This refers to the importance of other research, with other approaches and in other settings.

\section{REFERENCES}

1. Castro CP, Campos GWS. Apoio Institucional Paidéia como estratégia para educação permanente em saúde. Trab Educ Saúde [Internet]. 2014 Jan/Apr; [cited 2018 Aug 6]; 12(1):29-50. Available from: http://www.scielo.br/scielo.php?script=sci arttext\&pid=S1981-77462014000100003
2. Figueiredo MD, Campos GWS. O Apoio Paideia como metodologia para processos de formação em saúde. Interface (Botucatu) [Internet] 2014; [cited 2018 Aug 3]; 18(Suppl.1):931-43. Available from: http://www. scielo.br/scielo.php?pid=S1414-32832014000500931\&script=sci_ abstract\&tlng=pt

3. Castro CP, Campos GWS. Apoio Matricial como articulador das relações interprofissionais entre serviços especializados e atenção primária à saúde. Physis (Rio de Janeiro) [Internet]. 2016; [cited 2018 Aug 11]; 26(2):455-81. Available from: http://www.gastaowagner.com.br/index. php?preview $=1 \&$ option=com_dropfiles\&format=\&task=frontfile.down oad\&catid $=20 \&$ id $=5 \& \mid$ temid $=1000000000000$

4. Gerhardt Neto MR, Medina TSS, Irdes A. Apoio Matricial em saúde mental na percepção dos profissionais especialistas. Aletheia [Internet]. 2014 Dec; [cited 2018 Aug 7]; 45:139-55. Available from: http://pepsic.bvsalud.org/scielo.php?script=sci_arttext\&pid $=$ S1413-03942014000200011

5. Vendruscolo C, Ferraz F, Prado ML, Kleba ME, Martini JG. Instâncias intersetoriais de gestão: movimentos para a reorientação da formação na Saúde. Interface (Botucatu) [Internet]. 2018; [cited $2018 \mathrm{Jul}$ 10]; 22(Supl. 1):1353-64. Available from: http://www.scielo.br/pdf/ icse/2018nahead/1807-5762-icse-1807-576220170180.pdf

6. Freire P. Pedagogia do oprimido. $59^{\mathrm{a}}$ ed. Rio de Janeiro: Paz e Terra; 2015.

7. Carvalho SOB, Duarte LR, Guerrero JMA. Parceria ensino e serviço em Unidade Básica de Saúde como cenário de ensino-aprendizagem. Trab Educ Saúde [Internet] 2015 Jan/Apr; [cited 2018 Jul 12]; 13(1):123-44. Available from: $\mathrm{http}: / / \mathrm{www}$. scielo.br/pdf/tes/v13n1/1981-7746-tes-19817746-sip00026.pdf

8. Vendruscolo C, Prado ML, Kleba ME. Reorientação do Ensino no SUS, para além do quadrilátero, o prisma da educação. Rev Reflex Ação [Internet]. 2016 Sep/Dec; [cited 2017 Apr 25]; 24(3):246-60. Available from: https://online.unisc.br/seer/index.php/reflex/article/view/5420/pd

9. Oliveira AMC, Dallari SG. Analysis of factors influencing and conditioning social participation in Primary Health Care. Saúde Debate [Internet]. 2017 Sep; [cited 2018 Jan 9]; 41(spe3):202-13. Available from: http://www.scielo.br/scielo.php?script=sci_arttext\&pid=S0103$11042017000700202 \&$ Ing $=\mathrm{pt}$

10. Vendruscolo C, Ferraz F, Prado ML, Kleba ME, Reibnitz KS. Integração ensino-serviço e sua interface no contexto da reorientação da formação na saúde. Interface (Botucatu). 2016; [cited 2018 Sept 22]; 20(59):101525. Available from: http://www.scielo.br/pdf/icse/v20n59/1807-5762icse-1807-576220150768.pdf

11. Corrêa AB, Reibnitz KS, Kloh D, Prado ML, Rodrigues J, Lima MM. Contribuições do programa Pró-saúde: uma visão dos egressos de enfermagem. Rev Enferm UFPE On Line (Recife) [Internet]. 2017 Feb [cited 2018 Aug 11]; 11(2):567-75. Available from: https://periodicos. ufpe.br/revistas/revistaenfermagem/article/viewFile/11975/145244

12. Yin RK. Estudo de caso: planejamento e métodos. $5^{\mathrm{a}}$ ed. Porto Alegre: Bookman; 2015.

13. Minayo MCS. O desafio do conhecimento: pesquisa qualitativa em saúde. 14ª ed. São Paulo: Hucitec; 2014.

14. Souza TP, Carvalho SR. Apoio territorial e equipe multirreferencial: cartografias do encontro entre o apoio institucional e a redução de danos nas ruas e redes de Campinas, SP, Brasil. Interface (Botucatu) [Internet].2014; [cited 2018 Sep 21]; 18(Supl.1):945-56. Available from http://www.scielo.br/pdf/icse/v18s1/1807-5762-icse-18-1-0945.pdf

15. Morais APP, Tanaka OY. Apoio matricial em saúde mental: alcances e limites na atenção básica. Saúde Soc [Internet]. 2012; [cited 2018 Jan 10]; 2(1):161-70. Available from: http://www.scielo.br/scielo. php?pid=S0104-12902012000100016\&script=sci_abstract\&tlng=pt

16. Silva KL, Matos JAV, França BD. A construção da educação permanente no processo de trabalho em saúde no estado de Minas Gerais, Brasil. Esc Anna Nery [Internet]. 2017; [cited 2018 Jun 3]; 21(4):e20170060. Available from: http://www.scielo.br/pdf/ean/v21n4/pt_1414-8145-ean2177-9465-EAN-2017-0060.pdf 
17. Winters JRF, Prado ML, Waterkemper R, Kempfer SS. Dialogical and Participative Training in Nursing Education: contribution to the development of critical and reflective and creative thinking of students. Rev Min Enferm [Internet] 2017; [cited 2018 Aug 8];21:e-1067. Available from: http://www.reme.org.br/artigo/detalhes/1205

18. Kahan B. Using a comprehensive best practices approach to strengthen ethical health-related practice. Health Promot Pract [Internet]. 2012 Jul; [cited 2018 Mar 20]; 13(4):431-7. Available from: https://www.ncbi.nIm. nih.gov/pubmed/22764139

19. Macedo APMC. Nursing supervision: studying the "Case" of the phenomenon of interorganizational articulation nursing school and hospital. Rev Esc Enferm USP [Internet]. 2014; [cited 2016 Feb 12]; 48(no.esp2):190-6. Available from: http://www.scielo.br/pdf/reeusp/ v48nspe2/0080-6234-reeusp-48-nspe2-00190.pdf

20. Cavalcante RB, Esteves CJS, Pires MCA, Vasconcelos DD, Freitas MM, Macedo AS. A teoria ator-rede como referencial teórico-metodológico em pesquisas em saúde e enfermagem. Text Context Enferm [Internet]. 2017 Nov; [cited 2018 Aug 4]; 26(4):e0910017. Available from: http://www.scielo.br/scielo.php?script=sci_arttext\&pid=S010407072017000400302\&Ing=en

21. Gigante RL, Campos GWS. Política de formação e educação permanente em saúde no Brasil: bases legais e referências teóricas. Trab Edu Saúde [Internet]. 2016; [cited 2018 Aug 3]; 14(3):74763. Available from: http://www.scielo.br/scielo.php?script=sci_ arttext\&pid=S1981-77462016000300747\&lng=en\&nrm=iso

22. Moura $\mathrm{RH}$, Luzio $\mathrm{CA}$. O apoio institucional como uma das faces da função apoio no Núcleo de Apoio à Saúde da Família (NASF): para além das diretrizes. Interface (Botucatu) [Internet]. 2014;18(Supl. 1):957-70. Available from: http://www.scielo.br/pdf/icse/v18s1/18075762-icse-1807-576220130333.pdf

23. Sant'Anna SR, Hennington EA. Micropolítica do trabalho vivo em ato, ergologia e educação popular: proposição de um dispositivo de formação de trabalhadores da saúde. Trab Edu Saúde (Rio de Janeiro) [Internet]. 2011; [cited 2018 Aug 3]; 9(Supl. 1):223-44. Available from: http://www.scielo.br/pdf/tes/v9s1/11.pdf

24. Carvalho M, Santos NR, Campos GWS. A construção do SUS e o planejamento da força de trabalho em saúde no Brasil: breve trajetória histórica. Saúde Debate [Internet]. 2013 Sep; [cited 2010 Jul 25]; 37(98):372-87. Available from: http://www.scielo.br/scielo. php?script=sci_arttext\&pid=S0103-11042013000300002\&lng=pt

25. Zodpey S, Sharma A. Advancing reforms agenda for health professionals' education through transformative learning. Indian J Public Health [Internet]. 2014 Dec; [cited 2018 Jun 1]; 58(4):219-23. Available from: http://www.ijph.in/text.asp?2014/58/4/219/146274

26. Junges KS, Behrens MA. Prática docente no Ensino Superior: a formação pedagógica como mobilizadora de mudança. Perspectiva (Florianópolis) [Internet]. 2015 Jan/Apr; [cited 2018 Aug 10]; 33(1):285317. Available from: https://periodicos.ufsc.br/index.php/perspectiva/ article/view/2175-795X.2014v33n1p285/31220

27. D'Amour D, Goulet L, Labadie JF, Martín-Rodriguez LS, Pineault R. A model and typology of collaboration between professionals in healthcare organizations. BMC Health Serv Res [Internet]. 2008 Sep; [cited 2018 Aug 2]; 8:188. Available from: https://bmchealthservres. biomedcentral.com/articles/10.1186/1472-6963-8-188

a Pet-Saúde - Programa de Educação pelo Trabalho (freely translated as Education for Work Program), taking into account the assumptions of Permanent Education in Health, promotes the integration of teaching and service, through the possibility of learning in the practice settings of the public health network, allowing the demands of services to be a source of knowledge production and research. In the Pró/Pet announcement, in 2011, the articulation between the Pró and Pet-Saúde actions was idealized. This edict highlights the need for Pet groups to be linked to the Pedagogical Plans of Courses (PPC), in order to opportune the involvement of professors and students, including non-scholars. 7,16 